\title{
Role of In-Service Promoted Secondary School Heads in Strengthening Secondary Education in Kohat
}

\author{
Division, Pakistan
}

\author{
Qaiser Suleman \\ M.Phil (Education) Scholar, Institute of Education \& Research, Kohat University of Science \\ \& Technology, Khyber Pakhtunkhwa, (Pakistan) \\ Email: Look_for_reality@yahoo.com
}

\section{Dr. Ishtiaq Hussain}

Assistant Professor, Institute of Education \& Research, Kohat University of Science \& Technology, Khyber Pakhtunkhwa, (Pakistan)

Email: dr.ishtiaqkust@gmail.com

\section{Humaira Tufail}

M.Phil (Education), Institute of Education \& Research, Kohat University of Science \& Technology, Khyber Pakhtunkhwa, (Pakistan)

Accepted: August 05, 2012 Published: September 22, 2012

Doi:10.5296/ijhrs.v3i1.3114 URL: http://dx.doi.org/10.5296/ijhrs.v3i1.3114

\begin{abstract}
The purpose of the study was to assess the role of in-service promoted secondary school heads in strengthening secondary education. All the teachers and students at secondary school level in Kohat Division, Khyber Pakhtunkhwa (Pakistan) constituted the population of the study. In order to ensure adequate representation of the population, 450 teachers and 900 students were selected as sample through simple random sampling technique. The study was descriptive in nature and questionnaire was used as research instrument for data collection. After collection of data, it was organized, tabulated, analyzed and interpreted. Statistical tools, i.e., simple percentage and chi square were used for the analysis of data. After analysis of the data, it was concluded that the overall administrative performance of in-service promoted secondary school heads was ineffective and unsatisfactory. They lack the qualities of effective leadership and successful administration. Based on findings, it is strongly recommended that a special professional training programme regarding school administration and management should be institutionalized so that in-service promoted secondary school heads may be equipped with the modern techniques of school management and administration.
\end{abstract}

Keywords: Role, In-service Promoted Secondary School Heads, Strengthening, Secondary 
Education

\section{Introduction}

Secondary education is the most important sub-sector of the entire education system. It not only provides middle level workers of the economy but it also acts as a feeder for the higher education. The quality of higher education, which is expected to generate high quality professionals in various fields of social, economic and political life of the country, depends upon the quality of secondary education. This level of education, therefore, requires to be organized in such a way that it should prepare young men and women for higher education, as well as to enable them to adjust with their practical lives meaningfully and productively (AIOU, 1998, p.2). Therefore, it is imperative to have an effective management at this level to achieve the pre-determined objectives of secondary education effectively. Good and competent educational managers can play their role to achieve these target objectives. Hence there is need of effective and competent educational mangers at this level. Therefore, competent and brilliant managers should be recruited for the enhancement of secondary education through transparent and competitive examinations.

Within the complex and multifaceted operation of schools in the 21st century, the principal plays a crucial role in strengthening the effectiveness of a school and also bring about improvements in school (Ibrahim, 2011). Education is a complex system and is considered a highly specialized field which requires an effective administration. Its efficient and well-organized administration needs technical competence, administrative capability and understanding educational developments in the world. The educational manager must be well-known with specialized teaching skills and methodologies, accurate evaluation methods to assess the performance of teachers and taught and possess the knowledge of curriculum development and functioning of an educational system. The school administrators play an important and crucial role in strengthening education system. They are responsible for ensuring a healthy and encouraging environment in schools to promote happiness and wellbeing of children (Paul and Jacobson, 1984). In any educational institution, a variety of activities are organized and planned for the attainment of pre-determined educational objectives. Any activity whether it is curricular or co-curricular is planned, organized and managed by the manger of the organization. Manager of an educational institution is the person who is legally responsible for the effective, efficient and successful operation of an educational organization (Hussain, 2005). The principal of a school is an educational manager or leader who promotes the success of all teachers by performing with integrity, fairness and in an ethical manner (Gupton, 2003).

The current paper was specially designed to assess the role of in-service promoted secondary school heads in strengthening secondary education. The findings of the study will be useful for in-service promoted secondary school heads as it will explore the weak areas of their administration and management. Therefore, it is expected that through the findings of this study they will improve their administration and management to ensure effective and favorable environment for teaching learning process. 


\section{Review of Related Literature}

Management is the process of accomplishing organizational goals or objectives by working with and through people and other organizational resources. The word management also refers to the individuals who lead and direct organizations or to a career dedicated to the task of guiding and directing organization (Certo, 2003). Management is a collection of various functions directed at the efficient and effective use of resources in the pursuit of organizational objectives or goals. He further explained that management is multi-functional process. Planning \& decision-making; organizing; leading; and controlling are the four basic functions of management (Griffin, 1997). Koontz and Heinz (1993) defines management as "management is the process which designs and maintains an atmosphere in which individuals are working collectively in groups to achieve pre-determined goals efficiently. Management is a process designed and planned to ensure the cooperation, participation and involvement of others in an effective attainment of pre-determined educational objectives. Educational management has the four basic functions i.e., planning; organizing; decision-making; and controlling (Zaki, 1988). According to Rao and Narayana (1991), management is the process of planning, organizing, directing and controlling to achieve organizational objectives by the coordinated use of human and material resources. Franklin \& Terry (2000) define management as "management is the achievement or accomplishment of consequences through the efforts of other people". The two words management and administration are generally considered synonymous but it is relatively wrongly used. The term administration is related with the determination of commercial policy and the overall management or organization of production, distribution and finance. The term management means the implementation or execution of the policy within the limits which are devised by administration and the employment of the organization as required. Organization means the form of the enterprise or institution and the arrangement of the human and material resources executing in a way to accomplish the objectives of the enterprise. Administration explains the goals and management makes every effort to attain these goals (Nwankwo, 1981). Management is a primary and basic instrument in all the organization. It is the efficient and economical use of time, money and materials or some other unsought results to accomplish pre-determined goals and objectives (Sheikh, 1985).

Administration in any organization is involved in several rational functions i.e. planning, organizing, coordinating, evaluating, delegating, controlling and other similar activities. These functions are usually considered the same with leadership and this administrative leadership is considered as something to be applied on the organization or association in a manner that organizational objectives are more efficiently pursued (Sharma, 1994). Administration is process by which proper human and material resources are made available and these resources may effective to attain the objectives of an enterprise (Best, 1991). Administration is an important part of any organization and a social process which is concerned with identifying, maintaining, motivating, controlling and unifying formally and informally organized human and material resources within an integrated system. This system is designed especially to attain pre-determined goals or objectives (Musaazi, 1987). 
According to Kenneth (1984), educational administration is always concerned with management of things and human relationship based on a body of fundamental principles and aims at educating and humanizing the children and the youth. Educational administration has to carry out various functions like planning, organizing, directing and motivating, controlling, coordinating decision-making, evaluating, recording and reporting etc to make the education process more effective, successful and productive. The school principals or head teachers are the foundation stone in the process of school administration. They are one of the primary positions that emerged in the profession of educational administration. The word principal was drawn from prince and means first in rank, degree, importance and authority. Therefore, the principal is an individual that possesses the powers or authority to make decisions on the functioning of the school (Tahira, 2005). According to Farooq and Haffizullah (1990), "the head is an educational manager, educational leader, educational administrator, instructor, supervisor, architect, academician, educationist, educator and educational planner. $\mathrm{He} / \mathrm{she}$ has to make decisions and to keep his/her eyes open on the accomplishment of objectives of an organized group of people toward goals of educational policy. He/she has to control the activities of an organized group towards the attainment of goals. He/she should be a brilliant and an outstanding figure of the group. Khatoon (2008) stated that head teacher is the main and focal person in school administration. He is liable for bringing the national change with his capability and unique personality. He is the spokesperson of the department and the leader of teachers. Head teacher is an organizer, manager, supervisor and administrator. He has to carry out many fold duties. He has to cope with students, teachers, parents, other officers and colleagues of the other departments. According to Obemeata (1984), principal is a manager, an administrator, an exemplary leader, a counselor, a public officer, a nurse and even a messenger.

In order to attain the organizational goals effectively, head must strengthens the effectiveness of usual school programmes by avoiding waste of talents and physical recourses, by controlling budget and by planning ahead of the academic session. Head should plan intelligently, democratically and then take steps according to the situation (requirements of students and teachers, local customs and tradition) (Khatoon, 2007). School leadership has become a priority in education policy agendas at international level. It plays an important and crucial role in enhancing school outcomes by influencing the motivations and abilities of teachers, as well as the school environment. Effective and successful school leadership is imperative to improve the efficiency and equity of schooling (Pont et al., 2008). Goldring (1997) describes that "heads integrate, facilitate and organize many facets of the interior functions of the schools with the intention that objectives and visions can be realized. They are not only concern with what but also with how. Heads have not only to perform as facilitator or evaluator of teaching and methods of students learning but they have to facilitate the work of teachers". Effective and successful principalship is directly associated with school effectiveness. According to Mulford (1996), an effective and successful school is that school in which there is a sense of mission, high expectations, academic focus, feedback as academic performance, positive motivation strategies, ordered community climate, conscious attention to a positive safe, administrative leadership, teachers taking responsibility, parental 
involvement and a support system. The principal should manifest certain leadership behaviours that could build up a school of educational excellence. He/she should ensure encouraging and favorable environment that would develop a sound culture of teaching and learning.

According to Arikewuyo (1999), principal perform various functions for the advancement of a school. The principal perform the following functions:

- Principal provides leadership for curriculum development;

- $\mathrm{He} / \mathrm{she}$ provides leadership for instruction improvement;

- He/she ensures an environment that is conducive and encouraging for the realization of human potentials;

- He/she influences and controls the behavior of staff members; and

- $\mathrm{He} / \mathrm{she}$ also supervises the instructional activities in the school system.

The Commonwealth Secretariat (1993) also explained the functions of the Principal which are explained as follows:

- Principal manages and organizes school resources efficiently;

- He/she allocates school accommodation properly;

- He/she ensures the maintenance and cleanliness of school facilities and buildings;

- He/she organizes staff development in school;

- He/she guides and aids in curriculum implementation and change;

- He/she manages the developmental evaluation system, entire school evaluation and new integrated quality management system;

- He/she creates a professional culture inside the school through the involvement of staff members in decision-making, and

- He/she manages restructuring and redeployment of teaching staff.

Aremides (2003) suggested the following needs for effective headship at secondary level. Therefore, head must receive training to fulfill the following needs:

- Sufficient academic and professional qualification;

- A sound knowledge of the techniques and methodologies of educational practices

- A capability to provide professional leadership to all sections of the school community;

- An understanding of the interdependence of the different sections of the school community;

- An understanding of school finance and accounting procedures;

- A capability and skill to know each part of the school curriculum and how each part associates to the learning programme all together;

- An ability to plan ahead to bring such plans to complete fruition, an ability to communicate with, stimulate, motivate and bring into line the various sections of the school community to perform for the wellbeing of the school; 
- An ability to maintain sound public relations with those sections of the public with an interest in the school, a capability to execute effectively and efficiently with, and through others.

- A complete understanding of both the national educational goals as well as the operation of the school.

According to Nelly (2008), the following are the roles and responsibilities of a secondary school Manager:

\section{Management of Personnel and Students}

- Official duties and responsibilities: He/She is responsible to implement laws and regulations governing education. He/she has to participate in ceremonies. He/she is also responsible to send and mail official letters and other documents to the concerned authorities and represents the school at functions;

- Manager's role: He/she is responsible for the performance of personnel, for staff motivation and counseling.

- He/she is responsible to assesses staff activities, school and extra-curricular activities.

- $\mathrm{He} / \mathrm{she}$ is responsible to ensure discipline among staff and students.

- He/she is responsible to develop and promote socio-cultural activities and income generating activities.

- $\mathrm{He} / \mathrm{she}$ is responsible to propose and implement strategies for inspiring staff and students.

- $\mathrm{He} / \mathrm{she}$ is responsible to ensure sufficient feeding of students.

- $\mathrm{He} / \mathrm{she}$ is bound to attend health and hygiene matters in the school.

- $\mathrm{He} / \mathrm{she}$ is responsible to carry out pedagogic inspections.

- He/she is responsible to assign tasks and hand over duties among the personnel.

\section{Communications}

- He/she is responsible to acquire information from formal and informal resources about personnel performance and students' achievements

- $\mathrm{He} / \mathrm{she}$ is responsible to convey information to teachers, learners, parents and other stakeholders;

- $\mathrm{He} / \mathrm{she}$ is responsible to prepare and preside over pedagogic meetings

- $\mathrm{He} / \mathrm{she}$ has to make and prepare quarterly and occasional reports

\section{Decision-Making}

- He/she is responsible to manage and supervise the preparation of school action plans

- $\mathrm{He} / \mathrm{she}$ is also responsible to organize and coordinate school activities

- Entrepreneurial role: to seek for constructive and useful ideas, to plan activities, and to introduce new projects; 


\section{Macrothink}

- Negotiator: to discuss on school problems with teachers and also to find out the solutions to these problems.

- $\mathrm{He} / \mathrm{she}$ is responsible to manage school assets, properties and resources

According to Katozai (2002), the following are the qualities of a good headmaster:

- The first and the most important quality of a good headmaster is that he should have a great love and interest for his profession. On one hand he is the head and leader of the school while on the other hand he is a teacher. Therefore, he should take interest in teaching activities also.

- The headmaster should be a qualified man and his knowledge is his chief weapon. He should possess knowledge about teaching methodologies, educational psychology, organization and hygienic principles. He should have up-to-date knowledge of the educational theories and principles presented by modern educationists.

- The headmaster should be a model for teachers as well as for students. Therefore, he should possess a good personality. He should be clean, well dressed, neat and a healthy person.

- The headmaster should be a bold and daring personality. He should not be afraid of anyone except Allah. Then he will be capable to enforce his good ideas and to accept only good ideas of others. However, his power should not corrupt him. He should not be a monarch. He should boldly fight against all the evils presented in the school.

- He should not be a narrow-minded. He should accept the ideas and suggestions of others. He should be free from greed and jealousy.

- The headmaster should be punctual and come to school in time. If he comes late, then his subordinates will also come late and thus he will not be a good administrator.

- There are several problems in the school relating to the organization, seating arrangement, allocation of work and other administrative problems. The headmaster should, therefore, have the capability to overcome all these problems effectively.

- Discipline is very imperative for the process of education. Without discipline in the school, the educational atmosphere will be affected negatively. Therefore, the headmaster should be a good disciplinarian so that he may be able to put into practice all the rules and regulations upon the teachers, students and himself.

- The headmaster is unable to run the school efficiently without the co-operation of his subordinates. He should therefore, have good relation with the teachers, students and other personnel of the school. He should co-operate with them and help them in their problems.

The headmaster should be a critical man. He should not accept the bad ideas of others. He should criticize all the demerits and defects presented in teachers and departmental officials. However, he should do so in a democratic manner. A headmaster should be a qualified and experienced person. He should know how to teach and administrate. He should keep himself in touch with the study of day-to-day research in the field of education and 


\section{Macrothink

especially organization. He should read such books which increase his professional knowledge. He should also know about all the subjects taught in the school. He should attend the educational meetings, seminars and conferences regularly.

According to Khan (2000), the following characteristics of head teachers are:

- He should have the quality of punctuality and also ensure the quality "first to come and last to leave".

- He should be well versed and must have the knowledge of different subjects taught in the school.

- He should possess necessary experiences of budget preparation, preparation of bills, SNE, maintenance of different school registers.

- He should have the skill of writing of ACRs, workbooks, drafting, preparation of time table, syllabus, scouting, games etc.

- He should possess the quality of tolerance and open-mindedness. He must arrange meetings with his personnel.

- He must have good relations with the public and with the district or agency education office. He may allow the community to make use of the school as community center after school time. Furthermore, he should participate in programmes organized by the community.

- He should be honest, sympathetic, virtuous, and have affection for the students, for the school, for the society and for the country.

- He should have the quality of good administrator. He should pay attention on cleanliness and keep the school green so that it may attract the visitors.

- He should keep good relations with the high authorities of the department.

- He should take at least two periods in a week so that he may remain in contact with students and have direct information about students' problems.

- He should know the school problems and must be capable to find out their solutions also.

- The head teacher should not ignore the performance of the teachers. He should go to their classes, evaluate their teaching and provide guidance on the spot. He should also check the notebooks of the students randomly.

- He must make different committees among the teachers for the interests and wellbeing of the students and school.

\section{Statement of the Problem}

The study was specially designed to investigate the role of in-service promoted secondary school heads in strengthening secondary education and also the weak areas of their management. Therefore, the statement of the problem was entitled as "Role of In-Service 
Promoted Secondary School Heads in Strengthening Secondary Education in Kohat Division (Pakistan)”.

\section{Objectives of the Problems}

The objectives of the study were:

1. to examine the role of in-service promoted secondary school heads in strengthening secondary education;

2. to investigate the weak areas of in-service promoted secondary school heads in strengthening secondary education; and

3. to suggest workable recommendations to improve the administrative performance of in-service promoted secondary school heads

\section{RESEARCH METHODOLOGY}

\section{Population of the Study}

All the teachers and students at secondary school level in Kohat Division, Khyber Pakhtunkhwa (Pakistan) constituted the population of the study.

\section{Delimitations of the Study}

The study was delimited to male heads, teachers and students. The study was also delimited to only two cadres of teachers i.e., SSTs and CT teachers. The study was further delimited to 90 out of 129 secondary schools in Kohat Division where in-service promoted secondary school heads were performing their duties.

\section{Sample \& Sampling Technique}

In order to ensure adequate representation of the population, 5 teachers and 10 students from each school were selected as sample through simple random sampling technique. In this way, a total 450 teachers and 900 students were selected.

\section{Research Instrumentation}

The study was descriptive in nature therefore a self-developed structured questionnaire was used as research instrument. It was designed on Five Likert Scales i.e. SA (Strongly Agree), A (Agree), UN (Undecided), SDA (Strongly Disagree) and DA (Disagree). Furthermore, it was composed of 22 closed ended items.

\section{Pilot Testing}

Validation and authentication of the research instrument is an important stage of research study for the achievement of exact and precise results. For this purpose, pilot testing was conducted in five secondary schools to remove the weaknesses, misconceptions and ambiguities of the questions in the questionnaire. So after pilot testing, questionnaire was revised and then its final version was prepared in the light of suggestions given by the experts.

\section{Validity and Reliability}




\section{Macrothink}

International Journal of Human Resource Studies

ISSN 2162-3058

2013, Vol. 3, No. 1

Validity is the degree to which study assess the same concept that the researcher is trying to measure. Validity of the questionnaire was checked by three experts having doctorate degrees in the field of education. Reliability is the degree of consistency that an instrument or data collection procedure demonstrates, while validity is the quality of the collection procedure of the data that enables it to measure what it intends to measure (Best and Kahn, 1998; Gay, 2005; Masrur, 2003). Cronbach's alpha reliability test was used to calculate the reliability of questionnaire through S.P.S.S (Statistical Package for Social Sciences) version 16. The reliability coefficient was found to be 0.82 for the questionnaire.

\section{Data Collection}

The researchers personally visited to the sample secondary schools and distributed the questionnaires among the participants. Complicated terms were first explained and then the participants were told to give appropriate and accurate response without any hesitation and free of bias. A total of 1350 questionnaires were distributed and 1350 responses were received i.e., $100 \%$ responses. In this way data was collected.

\section{Data Analysis}

After collection of data, it was organized, tabulated, analyzed and interpreted. The statistical tools i.e. simple percentage and chi square were used for the analysis of the data. The following formula was used for chi square test:

$$
\chi^{2}=\sum \frac{\left[\left(f_{o}-f_{e}\right)^{2}\right]}{f_{e}}
$$

Where

$$
\begin{aligned}
& \chi^{2}=\text { Chi-square } \\
& \Sigma=\text { Sum of } \\
& f_{0}=\text { Frequency of occurrence of observed } \\
& f_{e}=\text { Expected frequency }
\end{aligned}
$$

\section{Analysis and Interpretation of Data}

The paper was specially designed to evaluate the role of in-service promoted secondary schools heads in strengthening secondary education. The study was descriptive in nature and a self-developed structured questionnaire was used as research instrument. Statistical tools, 
i.e., percentage and chi square were used for the statistical treatment of the data. The whole statistical process is explained in detail as under:

Table 02: Your headmaster/principal has a good personality and possesses the qualities of a good manager.

\begin{tabular}{|c|c|c|c|c|c|c|c|c|}
\hline Category & $\mathbf{S A}$ & $\mathbf{A}$ & UD & DA & SDA & $\mathbf{N}$ & $\chi^{2}$ & p-value \\
\hline Teachers & $\begin{array}{c}\mathbf{0 6 2} \\
(13.8 \%)\end{array}$ & $\begin{array}{c}112 \\
(24.6 \%)\end{array}$ & $\begin{array}{c}\mathbf{0 1 4} \\
(03.1 \%)\end{array}$ & $\begin{array}{c}164 \\
(36.1 \%)\end{array}$ & $\begin{array}{c}098 \\
(21.6 \%)\end{array}$ & 450 & \multirow{3}{*}{01.32} & \multirow{3}{*}{0.86} \\
\hline Students & $\begin{array}{c}116 \\
(12.9 \%) \\
\end{array}$ & $\begin{array}{c}229 \\
(25.4 \%) \\
\end{array}$ & $\begin{array}{c}\mathbf{0 2 2} \\
(02.4 \%) \\
\end{array}$ & $\begin{array}{c}319 \\
(35.1 \%) \\
\end{array}$ & $\begin{array}{c}214 \\
(23.5 \%) \\
\end{array}$ & 900 & & \\
\hline Total & 178 & 341 & 036 & 483 & 312 & 1350 & & \\
\hline
\end{tabular}

Table 2 depicts that the calculated value of $\chi^{2}$ was found to be 01.32 which is statistically non-significant ( $p>0.05$ ) because it is less than the table value of $\chi^{2}$ at 0.05 level. Hence it explicitly shows that both teachers and students possess similar views about the statement. They both disagreed to the statement "Your headmaster/principal has a good personality and possesses the qualities of a good manager".

Table 03: Your headmaster/principal attitude towards teachers is friendly and sympathetic.

\begin{tabular}{|c|c|c|c|c|c|c|c|c|}
\hline Category & $\mathbf{S A}$ & $\mathbf{A}$ & UD & DA & SDA & $\mathbf{N}$ & $\chi^{2}$ & p-value \\
\hline Teachers & $\begin{array}{c}72 \\
(16.0 \%)\end{array}$ & $\begin{array}{c}122 \\
(27.1 \%)\end{array}$ & $\begin{array}{c}12 \\
(02.7 \%)\end{array}$ & $\begin{array}{c}152 \\
(33.7 \%)\end{array}$ & $\begin{array}{c}\mathbf{0 9 2} \\
(20.4 \%)\end{array}$ & 450 & \multirow{3}{*}{02.60} & \multirow{3}{*}{.63} \\
\hline Students & $\begin{array}{c}136 \\
(15.1 \%) \\
\end{array}$ & $\begin{array}{c}\mathbf{2 4 8} \\
(27.5 \%) \\
\end{array}$ & $\begin{array}{c}\mathbf{0 2 9} \\
(03.2 \%) \\
\end{array}$ & $\begin{array}{c}276 \\
(30.6 \%) \\
\end{array}$ & $\begin{array}{c}211 \\
(23.4 \%) \\
\end{array}$ & 900 & & \\
\hline Total & 208 & 370 & 041 & 428 & 303 & 1350 & & \\
\hline
\end{tabular}

Table 3 illustrates that the calculated value of $\chi^{2}$ was found to be 02.60 which is statistically non-significant ( $p>0.05$ ) because it is less than the table value of $\chi^{2}$ at 0.05 level. Thus, it plainly indicates that both teachers and students possess similar opinions about the statement. They both disagreed to the statement "Your headmaster/principal attitude towards teachers is friendly and sympathetic".

Table 04: Your headmaster/principal organizes and supervises school activities properly and regularly.

\begin{tabular}{lllllllll}
\hline Category & SA & A & UD & DA & SDA & N & $\chi^{2}$ & p-value \\
\hline
\end{tabular}




\begin{tabular}{|c|c|c|c|c|c|c|c|c|}
\hline Teachers & $\begin{array}{c}\mathbf{0 4 7} \\
(10.4 \%)\end{array}$ & $\begin{array}{c}\mathbf{0 9 6} \\
(21.3 \%)\end{array}$ & $\begin{array}{c}\mathbf{0 2 2} \\
(04.9 \%)\end{array}$ & $\begin{array}{c}\mathbf{1 8 8} \\
(41.7 \%)\end{array}$ & $\begin{array}{c}\mathbf{0 9 7} \\
(21.5 \%)\end{array}$ & 450 & \multirow{3}{*}{02.64} & \multirow{3}{*}{.62} \\
\hline Students & $\begin{array}{c}103 \\
(11.4 \%) \\
\end{array}$ & $\begin{array}{c}\mathbf{2 0 4} \\
(22.6 \%) \\
\end{array}$ & $\begin{array}{c}\mathbf{0 3 1} \\
(03.4 \%) \\
\end{array}$ & $\begin{array}{c}\mathbf{3 5 7} \\
(39.4 \%) \\
\end{array}$ & $\begin{array}{c}\mathbf{2 0 5} \\
(22.8 \%) \\
\end{array}$ & 900 & & \\
\hline Total & 150 & 300 & 053 & 545 & 302 & 1350 & & \\
\hline
\end{tabular}

Table 4 depicts that the calculated value of $\chi^{2}$ was found to be 02.64 which is statistically non-significant ( $p>0.05)$ because it is less than the table value of $\chi^{2}$ at 0.05 level. Hence, it obviously indicates that both teachers and students have similar opinions about the statement. They both disagreed to the statement "Your headmaster/principal organizes and supervises school activities properly and regularly".

Table 05: Your headmaster/principal solves teacher's service problems efficiently.

\begin{tabular}{|c|c|c|c|c|c|c|c|c|}
\hline Category & SA & $\mathbf{A}$ & UD & DA & SDA & $\mathbf{N}$ & $\chi^{2}$ & p-value \\
\hline Teachers & $\begin{array}{c}\mathbf{0 7 9} \\
(17.5 \%)\end{array}$ & $\begin{array}{c}121 \\
(26.9 \%)\end{array}$ & $\begin{array}{c}\mathbf{0 1 9} \\
(04.2 \%)\end{array}$ & $\begin{array}{c}149 \\
(33.1 \%)\end{array}$ & $\begin{array}{c}\mathbf{0 8 2} \\
(18.2 \%)\end{array}$ & 450 & \multirow{3}{*}{04.65} & \multirow{3}{*}{.32} \\
\hline Students & $\begin{array}{c}152 \\
(16.9 \%)\end{array}$ & $\begin{array}{c}219 \\
(24.3 \%)\end{array}$ & $\begin{array}{c}\mathbf{0 3 4} \\
(03.8 \%) \\
\end{array}$ & $\begin{array}{c}\mathbf{2 8 6} \\
(31.7 \%) \\
\end{array}$ & $\begin{array}{c}209 \\
(23.2 \%)\end{array}$ & 900 & & \\
\hline Total & 231 & 340 & 053 & 435 & 291 & 1350 & & \\
\hline
\end{tabular}

Table 5 shows that the calculated value of $\chi^{2}$ was found to be 04.65 which is statistically non-significant ( $p>0.05$ ) because it is less than the table value of $\chi^{2}$ at 0.05 level. So, it clearly indicates that both teachers and students have the same opinions about the statement. They both disagreed to the statement "Your headmaster/principal solves teacher's service problems efficiently".

Table 06: Your headmaster/principal arranges monthly formal meetings to discuss school problems.

\begin{tabular}{ccccccccr}
\hline Category & SA & A & UD & DA & SDA & N & $\chi^{\mathbf{2}}$ & p-value \\
\hline \multirow{2}{*}{ Teachers } & $\mathbf{0 4 8}$ & $\mathbf{1 2 6}$ & $\mathbf{0 2 1}$ & $\mathbf{1 8 3}$ & $\mathbf{0 7 2}$ & \multirow{4}{*}{ (550 } & & \\
& $(10.7 \%)$ & $(27.7 \%)$ & $(04.7 \%)$ & $(40.6 \%)$ & $(16.0 \%)$ & & & \\
\multirow{2}{*}{ Students } & $\mathbf{1 0 6}$ & $\mathbf{2 6 3}$ & $\mathbf{0 3 9}$ & $\mathbf{2 5 4}$ & $\mathbf{1 9 0}$ & $\mathbf{9 0 0}$ & $\mathbf{1 7 . 7 5} *$ & $\mathbf{. 0 0 0}$ \\
& $(11.8 \%)$ & $(29.2 \%)$ & $(04.3 \%)$ & $(28.2 \%)$ & $(21.1 \%)$ & & & \\
\cline { 1 - 6 } Total & $\mathbf{1 5 4}$ & $\mathbf{3 8 9}$ & $\mathbf{0 6 0}$ & $\mathbf{4 3 7}$ & $\mathbf{2 6 2}$ & $\mathbf{1 3 5 0}$ & & \\
\hline
\end{tabular}

*Significant $\quad(p<0.05) \quad$ df $=4 \quad$ table value of $\chi^{2}$ at 0.05 level $=9.488$

Table 6 indicates that the calculated value of $\chi^{2}$ was found to be 17.75 which is statistically significant $(p<0.05)$ because it is greater than the table value of $\chi^{2}$ at 0.05 level. Hence it clearly depicts that teachers and students possess slight different views about the statement. 


\section{Macrothink}

International Journal of Human Resource Studies

ISSN 2162-3058

The opinions of the teachers are more negative as compared to the opinions of the students. But overall they both disagreed to the statement "Your headmaster/principal arranges monthly formal meetings to discuss school problems".

Table 07: Your headmaster/principal invites parents to discuss the student's disruptive behaviour and also their academic problems.

\begin{tabular}{|c|c|c|c|c|c|c|c|c|}
\hline Category & $\mathbf{S A}$ & $\mathbf{A}$ & UD & DA & SDA & $\mathbf{N}$ & $\chi^{2}$ & p-value \\
\hline Teachers & $\begin{array}{c}\mathbf{0 5 7} \\
(12.7 \%)\end{array}$ & $\begin{array}{c}099 \\
(22.0 \%)\end{array}$ & $\begin{array}{c}\mathbf{0 1 6} \\
(03.6 \%)\end{array}$ & $\begin{array}{c}179 \\
(39.7 \%)\end{array}$ & $\begin{array}{c}099 \\
(22.0 \%)\end{array}$ & 450 & \multirow{3}{*}{01.34} & \multirow{3}{*}{.85} \\
\hline Students & $\begin{array}{c}132 \\
(14.7 \%) \\
\end{array}$ & $\begin{array}{c}186 \\
(20.5 \%) \\
\end{array}$ & $\begin{array}{c}\mathbf{0 3 6} \\
(04.0 \%) \\
\end{array}$ & $\begin{array}{c}349 \\
(38.7 \%) \\
\end{array}$ & $\begin{array}{c}197 \\
(21.9 \%)\end{array}$ & 900 & & \\
\hline Total & 189 & 285 & 052 & 528 & 296 & 1350 & & \\
\hline
\end{tabular}

Table 7 depicts that the calculated value of $\chi^{2}$ was found to be 01.34 which is statistically non-significant ( $p>0.05$ ) because it is less than the table value of $\chi^{2}$ at 0.05 level. Hence it clearly indicates that both teachers and students possess similar opinions about the statement. They both disagreed to the statement "Your headmaster/principal invites parents to discuss the student's disruptive behaviour and also their academic problems".

Table 08: Your headmaster/principal provides facilities for teaching and non-teaching staff.

\begin{tabular}{ccccccccc}
\hline Category & SA & A & UD & DA & SDA & N & $\chi^{2}$ & p-value \\
\hline \multirow{2}{*}{ Teachers } & $\mathbf{0 6 8}$ & $\mathbf{1 3 4}$ & $\mathbf{0 2 4}$ & $\mathbf{1 5 2}$ & $\mathbf{0 7 2}$ & \multirow{4}{*}{ 450 } & & \\
& $(15.1 \%)$ & $(29.7 \%)$ & $(05.3 \%)$ & $(33.7 \%)$ & $(16.0 \%)$ & & & \\
Students & $\mathbf{1 2 6}$ & $\mathbf{2 7 6}$ & $\mathbf{0 3 5}$ & $\mathbf{2 8 8}$ & $\mathbf{1 7 5}$ & $\mathbf{9 0 0}$ & $\mathbf{4 . 0 0}$ & 0.41 \\
\cline { 1 - 5 } Total & $\mathbf{1 9 4}$ & $\mathbf{4 1 0}$ & $\mathbf{0 5 9}$ & $\mathbf{4 4 0}$ & $\mathbf{2 4 7}$ & $\mathbf{1 3 5 0}$ & & \\
\cline { 1 - 5 }
\end{tabular}

Non-Significant $\quad(p>0.05) \quad$ df $=4 \quad$ table value of $\chi^{2}$ at 0.05 level $=9.488$

Table 8 indicates that the calculated value of $\chi^{2}$ was found to be 04.00 which is statistically non-significant $(p>0.05)$ because it is less than the table value of $\chi^{2}$ at 0.05 level. So, it unambiguously shows that both teachers and students possess similar opinions about the statement. They both disagreed to the statement "Your headmaster/principal provides facilities for teaching and non-teaching staff".

Table 09: Your headmaster/principal ensures satisfactory standards of maintenance and cleanliness of school facilities. 


\begin{tabular}{|c|c|c|c|c|c|c|c|c|}
\hline Category & $\mathbf{S A}$ & $\mathbf{A}$ & UD & DA & SDA & $\mathbf{N}$ & $\chi^{2}$ & p-value \\
\hline Teachers & $\begin{array}{c}\mathbf{0 5 0} \\
(11.1 \%)\end{array}$ & $\begin{array}{c}146 \\
(32.4 \%)\end{array}$ & $\begin{array}{c}\mathbf{0 1 8} \\
(04.0 \%)\end{array}$ & $\begin{array}{c}162 \\
(36.0 \%)\end{array}$ & $\begin{array}{c}\mathbf{0 7 4} \\
(16.4 \%)\end{array}$ & 450 & \multirow{3}{*}{ 31.01* } & \multirow{3}{*}{.000} \\
\hline Students & $\begin{array}{c}116 \\
(12.9 \%)\end{array}$ & $\begin{array}{c}236 \\
(26.2 \%)\end{array}$ & $\begin{array}{c}\mathbf{0 3 2} \\
(03.6 \%)\end{array}$ & $\begin{array}{c}309 \\
(34.3 \%)\end{array}$ & $\begin{array}{c}207 \\
(23.0 \%)\end{array}$ & 900 & & \\
\hline Total & 166 & 382 & 050 & 471 & 281 & 1350 & & \\
\hline
\end{tabular}

*Significant $\quad(p<0.05) \quad$ df $=4 \quad$ table value of $\chi^{2}$ at 0.05 level $=9.488$

Table 9 shows that the calculated value of $\chi^{2}$ was found to be 31.01 which is statistically significant $(\mathrm{p}<0.05)$ because it is greater than the table value of $\chi^{2}$ at 0.05 level. It obviously indicates that teachers and students have slight different views about the statement. The opinions of the students are more negative as compared to the opinions of the teachers. But overall they both disagreed to the statement "Your headmaster/principal ensures satisfactory standards of maintenance and cleanliness of school facilities".

Table 10: Your headmaster/principal keeps update the school records regularly.

\begin{tabular}{|c|c|c|c|c|c|c|c|c|}
\hline Category & SA & $\mathbf{A}$ & UD & DA & SDA & $\mathbf{N}$ & $\chi^{2}$ & p-value \\
\hline Teachers & $\begin{array}{c}162 \\
(36.0 \%)\end{array}$ & $\begin{array}{c}144 \\
(32.0 \%)\end{array}$ & $\begin{array}{c}\mathbf{0 1 8} \\
(04.0 \%)\end{array}$ & $\begin{array}{c}\mathbf{0 5 0} \\
(11.1 \%)\end{array}$ & $\begin{array}{c}\mathbf{0 7 6} \\
(16.9 \%)\end{array}$ & 450 & & \\
\hline Students & $\begin{array}{c}309 \\
(34.3 \%) \\
\end{array}$ & $\begin{array}{c}234 \\
(26.0 \%) \\
\end{array}$ & $\begin{array}{c}\mathbf{0 3 2} \\
(03.6 \%) \\
\end{array}$ & $\begin{array}{c}118 \\
(13.1 \%) \\
\end{array}$ & $\begin{array}{c}\mathbf{2 0 7} \\
(23.0 \%) \\
\end{array}$ & 900 & $10.57 *$ & .03 \\
\hline Total & 471 & 378 & 050 & 168 & 283 & 1350 & & \\
\hline
\end{tabular}

Table 10 illustrates that the calculated value of $\chi^{2}$ was found to be 10.57 which is statistically significant $(\mathrm{p}<0.05)$ because it is greater than the table value of $\chi^{2}$ at 0.05 level. So, it plainly shows that teachers and students possess slight different views about the statement. The opinions of the teachers are more positive as compared to the opinions of the students. But overall they both agreed to the statement "Your headmaster/principal keeps update the school records regularly".

Table 11: Your headmaster/principal is cooperative and democratic minded.

\begin{tabular}{|c|c|c|c|c|c|c|c|c|}
\hline Category & SA & $\mathbf{A}$ & UD & DA & SDA & $\mathbf{N}$ & $\chi^{2}$ & p-value \\
\hline Teachers & $\begin{array}{c}\mathbf{0 5 7} \\
(12.7 \%)\end{array}$ & $\begin{array}{c}148 \\
(32.9 \%)\end{array}$ & $\begin{array}{c}\mathbf{0 2 3} \\
(05.1 \%)\end{array}$ & $\begin{array}{c}162 \\
(36.0 \%)\end{array}$ & $\begin{array}{c}\mathbf{0 6 0} \\
(13.3 \%)\end{array}$ & 450 & \multirow{3}{*}{02.30} & \multirow{3}{*}{.68} \\
\hline Students & $\begin{array}{c}106 \\
(11.8 \%) \\
\end{array}$ & $\begin{array}{c}279 \\
(31.0 \%) \\
\end{array}$ & $\begin{array}{c}\mathbf{0 3 8} \\
(04.2 \%) \\
\end{array}$ & $\begin{array}{c}\mathbf{3 3 6} \\
(37.3 \%) \\
\end{array}$ & $\begin{array}{c}141 \\
(15.7 \%) \\
\end{array}$ & 900 & & \\
\hline Total & 163 & 427 & 061 & 498 & 201 & 1350 & & \\
\hline
\end{tabular}




\section{Macrothink}

Table 11 indicates that the calculated value of $\chi^{2}$ was found to be 02.30 which is statistically non-significant ( $p>0.05$ ) because it is less than the table value of $\chi^{2}$ at 0.05 level. Hence, it clearly depicts that both teachers and students have similar opinions about the statement. They both disagreed to the statement "Your headmaster/principal is cooperative and democratic minded".

Table 12: Your headmaster/principal follows and implements relevant federal and provincial rules and policies more effectively in school.

\begin{tabular}{|c|c|c|c|c|c|c|c|c|}
\hline Category & $\mathbf{S A}$ & $\mathbf{A}$ & UD & DA & SDA & $\mathbf{N}$ & $\chi^{2}$ & p-value \\
\hline Teachers & $\begin{array}{c}\mathbf{0 6 1} \\
(15.5 \%)\end{array}$ & $\begin{array}{c}129 \\
(28.4 \%)\end{array}$ & $\begin{array}{c}\mathbf{0 2 8} \\
(06.2 \%)\end{array}$ & $\begin{array}{c}173 \\
(38.1 \%)\end{array}$ & $\begin{array}{c}\mathbf{0 5 9} \\
(13.1 \%)\end{array}$ & 450 & & \\
\hline Students & $\begin{array}{c}116 \\
(12.9 \%) \\
\end{array}$ & $\begin{array}{c}242 \\
(26.9 \%) \\
\end{array}$ & $\begin{array}{c}\mathbf{0 3 7} \\
(04.1 \%) \\
\end{array}$ & $\begin{array}{c}359 \\
(39.8 \%) \\
\end{array}$ & $\begin{array}{c}146 \\
(16.2 \%) \\
\end{array}$ & 900 & 05.30 & .26 \\
\hline Total & 177 & 371 & 065 & 532 & 205 & 1350 & & \\
\hline
\end{tabular}

Non-Significant $\quad(p>0.05) \quad$ df $=4 \quad$ table value of $\chi^{2}$ at 0.05 level $=9.488$

Table 12 illustrates that the calculated value of $\chi^{2}$ was found to be 05.30 which is statistically non-significant ( $p>0.05$ ) because it is less than the table value of $\chi^{2}$ at 0.05 level. So, it clearly indicates that both teachers and students possess similar views about the statement. They both disagreed to the statement "Your headmaster/principal follows and implements relevant federal and provincial rules and policies more effectively in school".

Table 13: Your headmaster/principal possesses the knowledge of effective administration, teaching methods, educational psychology and school management.

\begin{tabular}{|c|c|c|c|c|c|c|c|c|}
\hline Category & $\mathbf{S A}$ & $\mathbf{A}$ & UD & DA & SDA & $\mathbf{N}$ & $\chi^{2}$ & p-value \\
\hline Teachers & $\begin{array}{c}\mathbf{0 4 2} \\
(09.3 \%)\end{array}$ & $\begin{array}{c}119 \\
(26.4 \%)\end{array}$ & $\begin{array}{c}\mathbf{0 2 6} \\
(05.8 \%)\end{array}$ & $\begin{array}{c}173 \\
(38.4 \%)\end{array}$ & $\begin{array}{c}\mathbf{0 9 0} \\
(20.0 \%)\end{array}$ & 450 & & \\
\hline Students & $\begin{array}{c}\mathbf{0 7 8} \\
(08.6 \%) \\
\end{array}$ & $\begin{array}{c}219 \\
(24.3 \%) \\
\end{array}$ & $\begin{array}{c}\mathbf{0 4 2} \\
(04.7 \%) \\
\end{array}$ & $\begin{array}{c}\mathbf{3 6 5} \\
(40.5 \%) \\
\end{array}$ & $\begin{array}{c}196 \\
(21.8 \%) \\
\end{array}$ & 900 & 02.20 & .70 \\
\hline Total & 120 & 338 & 068 & 538 & 286 & 1350 & & \\
\hline
\end{tabular}

Table 13 depicts that the calculated value of $\chi^{2}$ was found to be 02.20 which is statistically non-significant $(p>0.05)$ because it is less than the table value of $\chi^{2}$ at 0.05 level. So, it plainly indicates that both teachers and students have similar views about the statement. They both disagreed to the statement "Your headmaster/principal possesses the knowledge of effective administration, teaching methods, educational psychology and school management".

Table 14: Your headmaster/principal encourages the teachers on showing good performance. 


\begin{tabular}{|c|c|c|c|c|c|c|c|c|}
\hline Category & $\mathbf{S A}$ & $\mathbf{A}$ & UD & DA & SDA & $\mathbf{N}$ & $\chi^{2}$ & p-value \\
\hline Teachers & $\begin{array}{c}\mathbf{0 6 6} \\
(14.7 \%)\end{array}$ & $\begin{array}{c}129 \\
(28.6 \%)\end{array}$ & $\begin{array}{c}\mathbf{0 2 2} \\
(04.9 \%)\end{array}$ & $\begin{array}{c}166 \\
(36.9 \%)\end{array}$ & $\begin{array}{c}\mathbf{0 6 7} \\
(14.9 \%)\end{array}$ & 450 & \multirow{3}{*}{08.06} & \multirow{3}{*}{0.09} \\
\hline Students & $\begin{array}{c}114 \\
(12.7 \%) \\
\end{array}$ & $\begin{array}{c}\mathbf{2 6 8} \\
(29.7 \%) \\
\end{array}$ & $\begin{array}{c}\mathbf{0 3 6} \\
(04.0 \%) \\
\end{array}$ & $\begin{array}{c}297 \\
(33.0 \%) \\
\end{array}$ & $\begin{array}{c}185 \\
(20.5 \%) \\
\end{array}$ & 900 & & \\
\hline Total & 180 & 397 & 058 & 463 & 252 & 1350 & & \\
\hline
\end{tabular}

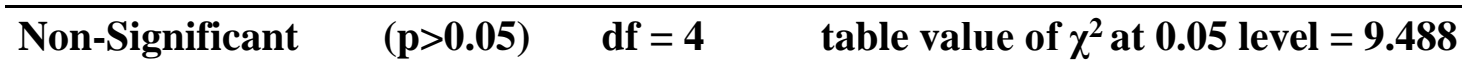

Table 14 indicates that the calculated value of $\chi^{2}$ was found to be 08.06 which is statistically non-significant ( $p>0.05$ ) because it is less than the table value of $\chi^{2}$ at 0.05 level. Hence, it obviously shows that both teachers and students possess the same views about the statement. They both disagreed to the statement "Your headmaster/principal encourages the teachers on showing good performance".

Table 15: Your headmaster/principal assesses student's performance regularly.

\begin{tabular}{|c|c|c|c|c|c|c|c|c|}
\hline Category & $\mathbf{S A}$ & $\mathbf{A}$ & UD & DA & SDA & $\mathbf{N}$ & $\chi^{2}$ & p-value \\
\hline Teachers & $\begin{array}{c}049 \\
(10.9 \%)\end{array}$ & $\begin{array}{c}138 \\
(30.6 \%)\end{array}$ & $\begin{array}{c}\mathbf{0 2 8} \\
(06.2 \%)\end{array}$ & $\begin{array}{c}164 \\
(36.4 \%)\end{array}$ & $\begin{array}{c}071 \\
(15.8 \%)\end{array}$ & 450 & \multirow{3}{*}{0.95} & \multirow{3}{*}{.92} \\
\hline Students & $\begin{array}{c}106 \\
(11.7 \%) \\
\end{array}$ & $\begin{array}{c}276 \\
(30.6 \%) \\
\end{array}$ & $\begin{array}{c}049 \\
(05.4 \%) \\
\end{array}$ & $\begin{array}{c}\mathbf{3 1 6} \\
(35.1 \%) \\
\end{array}$ & $\begin{array}{c}153 \\
(17.0 \%) \\
\end{array}$ & 900 & & \\
\hline Total & 155 & 414 & 077 & 480 & 224 & 1350 & & \\
\hline
\end{tabular}

Table 15 illustrates that the calculated value of $\chi^{2}$ was found to be 0.95 which is statistically non-significant ( $p>0.05$ ) because it is less than the table value of $\chi^{2}$ at 0.05 level. So, it clearly shows that both teachers and students possess similar opinions about the statement. They both disagreed to the statement "Your headmaster/principal assesses student's performance regularly".

Table 16: Your headmaster/principal awards students on showing excellent performance.

\begin{tabular}{|c|c|c|c|c|c|c|c|c|}
\hline Category & $\mathbf{S A}$ & $\mathbf{A}$ & UD & DA & SDA & $\mathbf{N}$ & $\chi^{2}$ & p-value \\
\hline Teachers & $\begin{array}{c}\mathbf{0 7 1} \\
(15.8 \%)\end{array}$ & $\begin{array}{c}139 \\
(30.9 \%)\end{array}$ & $\begin{array}{c}\mathbf{0 2 5} \\
(05.6 \%)\end{array}$ & $\begin{array}{c}\mathbf{0 2 5} \\
(05.6 \%)\end{array}$ & $\begin{array}{c}\mathbf{0 5 7} \\
(12.7 \%)\end{array}$ & 450 & & \\
\hline Students & $\begin{array}{c}132 \\
(14.7 \%) \\
\end{array}$ & $\begin{array}{c}\mathbf{2 6 2} \\
(29.1 \%) \\
\end{array}$ & $\begin{array}{c}\mathbf{0 4 1} \\
(05.6 \%) \\
\end{array}$ & $\begin{array}{c}\mathbf{3 3 6} \\
(37.3 \%) \\
\end{array}$ & $\begin{array}{c}129 \\
(14.3 \%) \\
\end{array}$ & 900 & 02.19 & .70 \\
\hline Total & 203 & 401 & 066 & 494 & 186 & 1350 & & \\
\hline
\end{tabular}

Table 16 depicts that the calculated value of $\chi^{2}$ was found to be 02.19 which is statistically non-significant ( $p>0.05$ ) because it is less than the table value of $\chi^{2}$ at 0.05 level. Hence, it 
obviously shows that both teachers and students have the same opinions about the statement. They both disagreed to the statement "Your headmaster/principal awards students on showing excellent performance".

Table 17: Your headmaster/principal provides financial assistance to poor students.

\begin{tabular}{|c|c|c|c|c|c|c|c|c|}
\hline Category & $\mathbf{S A}$ & $\mathbf{A}$ & UD & DA & SDA & $\mathbf{N}$ & $\chi^{2}$ & p-value \\
\hline Teachers & $\begin{array}{c}\mathbf{0 6 3} \\
(14.0 \%)\end{array}$ & $\begin{array}{c}116 \\
(25.8 \%)\end{array}$ & $\begin{array}{c}\mathbf{0 2 2} \\
(04.9 \%)\end{array}$ & $\begin{array}{c}176 \\
(39.1 \%)\end{array}$ & $\begin{array}{c}\mathbf{0 7 3} \\
(16.2 \%)\end{array}$ & 450 & \multirow{3}{*}{0.87} & \multirow{3}{*}{.93} \\
\hline Students & $\begin{array}{c}134 \\
(14.9 \%) \\
\end{array}$ & $\begin{array}{c}221 \\
(24.3 \%) \\
\end{array}$ & $\begin{array}{c}\mathbf{0 4 3} \\
(04.8 \%) \\
\end{array}$ & $\begin{array}{c}331 \\
(36.4 \%) \\
\end{array}$ & $\begin{array}{c}128 \\
(14.2 \%) \\
\end{array}$ & 900 & & \\
\hline Total & 197 & 337 & 065 & 507 & 201 & 1350 & & \\
\hline
\end{tabular}

Table 17 illustrates that the calculated value of $\chi^{2}$ was found to be 0.87 which is statistically non-significant ( $p>0.05$ ) because it is less than the table value of $\chi^{2}$ at 0.05 level. Hence, it plainly depicts that both teachers and students have similar opinions about the statement. They both disagreed to the statement "Your headmaster/principal provides financial assistance to poor students".

Table 18: Your headmaster/principal is a good disciplinarian and implements all rules and regulations upon teachers, students and himself effectively.

\begin{tabular}{|c|c|c|c|c|c|c|c|c|}
\hline Category & $\mathbf{S A}$ & $\mathbf{A}$ & UD & DA & SDA & $\mathbf{N}$ & $\chi^{2}$ & p-value \\
\hline Teachers & $\begin{array}{c}067 \\
(14.7 \%)\end{array}$ & $\begin{array}{c}129 \\
(28.6 \%)\end{array}$ & $\begin{array}{c}\mathbf{0 2 4} \\
(05.3 \%)\end{array}$ & $\begin{array}{c}162 \\
(36.0 \%)\end{array}$ & $\begin{array}{c}\mathbf{0 6 8} \\
(15.1 \%)\end{array}$ & 450 & \multirow{3}{*}{06.05} & \multirow{3}{*}{.20} \\
\hline Students & $\begin{array}{c}126 \\
(14.0 \%) \\
\end{array}$ & $\begin{array}{c}232 \\
(35.9 \%) \\
\end{array}$ & $\begin{array}{c}\mathbf{0 4 6} \\
(05.1 \%) \\
\end{array}$ & $\begin{array}{c}311 \\
(34.5 \%) \\
\end{array}$ & $\begin{array}{c}185 \\
(20.5 \%) \\
\end{array}$ & 900 & & \\
\hline Total & 193 & 361 & 070 & 473 & 253 & 1350 & & \\
\hline
\end{tabular}

Table 18 depicts that the calculated value of $\chi^{2}$ was found to be 06.05 which is statistically non-significant ( $>>0.05$ ) because it is less than the table value of $\chi^{2}$ at 0.05 level. It clearly indicates that both teachers and students have the same opinions about the statement. They both disagreed to the statement "Your headmaster/principal is a good disciplinarian and implement all rules and regulations upon teachers, students and himself effectively"

Table 19: Your headmaster/principal takes bold steps for the enhancement of schools activities. 


\begin{tabular}{|c|c|c|c|c|c|c|c|c|}
\hline Category & SA & $\mathbf{A}$ & UD & DA & SDA & $\mathbf{N}$ & $\chi^{2}$ & p-value \\
\hline Teachers & $\begin{array}{c}\mathbf{0 3 9} \\
(08.7 \%)\end{array}$ & $\begin{array}{c}109 \\
(24.2 \%)\end{array}$ & $\begin{array}{c}\mathbf{0 2 8} \\
(06.2 \%)\end{array}$ & $\begin{array}{c}183 \\
(40.6 \%)\end{array}$ & $\begin{array}{c}091 \\
(20.2 \%)\end{array}$ & 450 & \multirow{3}{*}{02.47} & \multirow{3}{*}{.65} \\
\hline Students & $\begin{array}{c}091 \\
(10.1 \%) \\
\end{array}$ & $\begin{array}{c}234 \\
(26.0 \%) \\
\end{array}$ & $\begin{array}{c}\mathbf{0 4 5} \\
(05.0 \%) \\
\end{array}$ & $\begin{array}{c}342 \\
(38.0 \%) \\
\end{array}$ & $\begin{array}{c}188 \\
(20.9 \%) \\
\end{array}$ & 900 & & \\
\hline Total & 130 & 343 & 073 & 525 & 279 & 1350 & & \\
\hline
\end{tabular}

Non-Significant $\quad(p>0.05) \quad$ df $=4 \quad$ table value of $\chi^{2}$ at 0.05 level $=9.488$

Table 19 indicates that the calculated value of $\chi^{2}$ was found to be 02.47 which is statistically non-significant ( $p>0.05$ ) because it is less than the table value of $\chi^{2}$ at 0.05 level. Hence, it explicitly shows that both teachers and students have similar opinions about the statement. They both disagreed to the statement "Your headmaster/principal takes bold steps for the enhancement of schools activities".

Table 20: Your headmaster/principal supervises teaching methodologies of teachers regularly.

\begin{tabular}{|c|c|c|c|c|c|c|c|c|}
\hline Category & $\mathbf{S A}$ & $\mathbf{A}$ & UD & DA & SDA & $\mathbf{N}$ & $\chi^{2}$ & p-value \\
\hline Teachers & $\begin{array}{c}\mathbf{0 3 6} \\
(08.0 \%)\end{array}$ & $\begin{array}{c}\mathbf{0 9 6} \\
(21.3 \%)\end{array}$ & $\begin{array}{c}\mathbf{0 2 6} \\
(05.8 \%)\end{array}$ & $\begin{array}{c}198 \\
(44.0 \%)\end{array}$ & $\begin{array}{c}\mathbf{0 9 4} \\
(20.9 \%)\end{array}$ & 450 & \multirow{3}{*}{04.78} & \multirow{3}{*}{0.31} \\
\hline Students & $\begin{array}{c}\mathbf{0 8 6} \\
(09.5 \%) \\
\end{array}$ & $\begin{array}{c}174 \\
(19.3 \%) \\
\end{array}$ & $\begin{array}{c}\mathbf{0 3 9} \\
(04.3 \%) \\
\end{array}$ & $\begin{array}{c}379 \\
(42.1 \%) \\
\end{array}$ & $\begin{array}{c}222 \\
(24.6 \%) \\
\end{array}$ & 900 & & \\
\hline Total & 122 & 270 & 065 & 577 & 316 & 1350 & & \\
\hline
\end{tabular}

Table 20 illustrates that the calculated value of $\chi^{2}$ was found to be 04.78 which is statistically non-significant ( $p>0.05$ ) because it is less than the table value of $\chi^{2}$ at 0.05 level. So, it clearly shows that both teachers and students possess the same opinions about the statement. They both disagreed to the statement "Your headmaster/principal supervises teaching methodologies of teachers regularly".

Table 21: Your headmaster/principal identifies the weakness of teachers and suggest corrective measure.

\begin{tabular}{|c|c|c|c|c|c|c|c|c|}
\hline Category & SA & $\mathbf{A}$ & UD & DA & SDA & $\mathbf{N}$ & $\chi^{2}$ & p-value \\
\hline Teachers & $\begin{array}{c}\mathbf{0 5 2} \\
(11.5 \%)\end{array}$ & $\begin{array}{c}119 \\
(26.4 \%)\end{array}$ & $\begin{array}{c}119 \\
(26.4 \%)\end{array}$ & $\begin{array}{c}162 \\
(36.0 \%)\end{array}$ & $\begin{array}{c}\mathbf{0 9 1} \\
(20.2 \%)\end{array}$ & 450 & \multirow{3}{*}{01.87} & \multirow{3}{*}{.76} \\
\hline Students & $\begin{array}{c}114 \\
(12.7 \%)\end{array}$ & $\begin{array}{c}234 \\
(26.0 \%) \\
\end{array}$ & $\begin{array}{c}\mathbf{0 4 1} \\
(04.6 \%) \\
\end{array}$ & $\begin{array}{c}342 \\
(38.0 \%) \\
\end{array}$ & $\begin{array}{c}169 \\
(18.8 \%) \\
\end{array}$ & 900 & & \\
\hline Total & 166 & 353 & 067 & 504 & 260 & 1350 & & \\
\hline
\end{tabular}




\section{Macrothink Institute ${ }^{\mathrm{TM}}$}

Table 21 indicates that the calculated value of $\chi^{2}$ was found to be 01.87 which is statistically non-significant ( $p>0.05$ ) because it is less than the table value of $\chi^{2}$ at 0.05 level. Hence, it undoubtedly shows that both teachers and students possess similar opinions about the statement. They both disagreed to the statement "Your headmaster/principal identifies the weakness of teachers and suggests corrective measure".

Table 22: Your headmaster/principal assesses student's performance regularly and fairly.

\begin{tabular}{|c|c|c|c|c|c|c|c|c|}
\hline Category & SA & $\mathbf{A}$ & UD & DA & SDA & $\mathbf{N}$ & $\chi^{2}$ & p-value \\
\hline Teachers & $\begin{array}{c}\mathbf{0 5 6} \\
(12.4 \%)\end{array}$ & $\begin{array}{c}124 \\
(27.5 \%)\end{array}$ & $\begin{array}{c}\mathbf{0 2 2} \\
(04.9 \%)\end{array}$ & $\begin{array}{c}168 \\
(37.3 \%)\end{array}$ & $\begin{array}{c}\mathbf{0 8 0} \\
(17.8 \%)\end{array}$ & 450 & & \\
\hline Students & $\begin{array}{c}099 \\
(11.0 \%) \\
\end{array}$ & $\begin{array}{c}\mathbf{2 5 6} \\
(28.4 \%) \\
\end{array}$ & $\begin{array}{c}\mathbf{0 4 6} \\
(05.1 \%) \\
\end{array}$ & $\begin{array}{c}\mathbf{3 4 2} \\
(38.0 \%) \\
\end{array}$ & $\begin{array}{c}157 \\
(17.4 \%) \\
\end{array}$ & 900 & 0.71 & .95 \\
\hline Total & 155 & 380 & 068 & 510 & 237 & 1350 & & \\
\hline
\end{tabular}

Table 22 depicts that the calculated value of $\chi^{2}$ was found to be 0.71 which is statistically non-significant ( $p>0.05$ ) because it is less than the table value of $\chi^{2}$ at 0.05 level. So, it plainly indicates that both teachers and students possess similar opinions about the statement. They both disagreed to the statement "Your headmaster/principal assesses student's performance regularly and fairly".

Table 23: Your headmaster/principal spends school and PTA funds for the interests and welfare of the school.

\begin{tabular}{|c|c|c|c|c|c|c|c|c|}
\hline Category & $\mathbf{S A}$ & $\mathbf{A}$ & UD & DA & SDA & $\mathbf{N}$ & $\chi^{2}$ & p-value \\
\hline Teachers & $\begin{array}{c}\mathbf{0 2 6} \\
(05.8 \%)\end{array}$ & $\begin{array}{c}\mathbf{0 8 6} \\
(19.1 \%)\end{array}$ & $\begin{array}{c}\mathbf{0 2 6} \\
(05.8 \%)\end{array}$ & $\begin{array}{c}\mathbf{2 0 8} \\
(46.2 \%)\end{array}$ & $\begin{array}{c}104 \\
(23.0 \%)\end{array}$ & 450 & \multirow{3}{*}{07.94} & \multirow{3}{*}{.09} \\
\hline Students & $\begin{array}{c}\mathbf{0 8 6} \\
(09.5 \%) \\
\end{array}$ & $\begin{array}{c}174 \\
(19.3 \%) \\
\end{array}$ & $\begin{array}{c}\mathbf{0 3 9} \\
(04.3 \%) \\
\end{array}$ & $\begin{array}{c}\mathbf{3 7 9} \\
(42.1 \%) \\
\end{array}$ & $\begin{array}{c}222 \\
(24.6 \%) \\
\end{array}$ & 900 & & \\
\hline Total & 112 & 260 & 065 & 587 & 326 & 1350 & & \\
\hline
\end{tabular}

Table 23 indicates that the calculated value of $\chi^{2}$ was found to be 07.94 which is statistically non-significant ( $p>0.05$ ) because it is less than the table value of $\chi^{2}$ at 0.05 level. Hence, it clearly shows that both teachers and students possess similar views about the statement. They both disagreed to the statement "Your headmaster/principal spends school and PTA funds for the interests and welfare of the school".

\section{Findings and Conclusions}

In the light of statistical analysis and findings of the study, the following 
conclusions were drawn:

1. The study revealed that the administrative performance of in-service promoted secondary school heads was extremely ineffective and unsatisfactory. They did not possess the qualities of good managers. They had no knowledge of effective administration, teaching methodologies, educational psychology and school management.

2. The study also exposed that the attitude of in-service promoted secondary school heads with teaching and non-teaching staff was not sympathetic and friendly. They were not interested to solve the service problems of teachers. They did not provide facilities for teaching and non-teaching personnel. They were not democratic minded.

3. It was also revealed through this study that in-service promoted secondary school heads did not supervise school activities properly. They did not pay their attention on maintenance and cleanliness of school facilities. They did not arrange monthly formal meetings to discuss school problems. They did not evaluate teaching methodologies of teachers.

4. The study also revealed that in-service promoted secondary school heads did not follow and implement relevant federal and provincial rules and policies effectively inside the school. They were not good disciplinarian and did not implement rules and regulations upon teachers, students and himself effectively. They had no ability to take bold steps for the enhancement of schools activities.

5. The study also exposed that in-service promoted secondary school heads did not award and encourage teachers and students on showing good performance. They did not assess student's performance regularly. They did not invite parents to discuss the student's related matters. They were not fair in spending school funds. They did not provide financial assistance to poor students.

\section{Concluding Remarks}

In nutshell, it is concluded that the overall administrative performance of in-service promoted secondary school heads was ineffective and unsatisfactory. They lack the qualities of an effective leadership and a successful administration. They are only the heads of institutions by name but their practical role and responsibilities were extremely unsatisfactory and disappointing.

\section{Recommendations}

In the light of findings and conclusions, the researchers suggest the following recommendations:

1. A special professional training programme regarding school management and administration should be institutionalized so that in-service secondary school heads may be equipped with the modern techniques of school management and administration.

2. According to the contemporary service structure, $75 \%$ secondary school teachers are promoted to the post of Headmaster without devising any criteria which allows poor and non-qualified teachers to become the heads of the institutions. Therefore, it is 
strongly recommended that $75 \%$ secondary school heads should be selected through competitive and transparent examination conducted by Khyber Pakhtunkhwa Public Service Commission.

3. Teacher education curricula should be revised and designed according to the emerging needs of school management. In this way competent and effective management will be ensured.

4. As the study revealed that majority of in-service promoted secondary school heads were not competent and skillful in school administration and management therefore, it is recommended that in-service promoted secondary school heads may be provided proper training before they are appointed as heads.

5. It is also recommended that in-service promoted secondary school heads should have the ability of better planning. They should arrange weekly personnel meetings to discuss the problems of their subordinates and school.

6. The In-service promoted secondary school heads should be a good disciplinarian and should implement disciplinary rules and regulations upon teachers, students and on himself effectively.

7. As it was found that the attitude of in-service promoted secondary school heads with subordinates was not sympathetic and friendly. Therefore, it is strongly recommended that they should be democratic minded and their attitude should be sympathetic and friendly. They should provide facilities for their teaching and non-teaching personnel. They should point out the weakness of teachers and suggest constructive and corrective measures.

8. In-service secondary school heads should evaluate the performance of teachers and students regularly. Teachers and students should be rewarded on showing excellent performance.

9. As it was found that in-service promoted secondary school heads were not fair in spending school funds for the welfare of the schools. Therefore it is strongly recommended that an effective check and balance system should be implemented to decrease the level of corruption in school funding.

\section{References}

Aremides, R. (2003). Training Needs Educational Managers at Secondary Level. http/www.dayton.net/rma/sms/htm.

A.I.O.U. (1998). Secondary Education. Study Guide for M.Ed, Code No. 827. Faculty of Education, Teacher Education Department, Allama Iqbal Open University, Islamabad. p. 2

Arikewuyo, M. O. (1999). Job Attitude Profiles of Managers of Secondary Schools in Nigeria. Life Psychologia, 7(2), 69-84.

Best, J. W. (1991). Research in Education (3rd Ed.), Englewood Cliffs. N. J; Prentice Hall. p.36

Best, J., and Kahn, J. (1998). Research in education (8th ed.). Boston: Allyn and Bacon.

Certo, S. C. (2003). Modern Management: Adding Digital Focus. New Delhi: India Prentice Hall of India private Limited. 
Commonwealth Secretariat (1993). Better Schools Resource Materials for School Heads: Module Three: Personnel Management. London: Paren and Stacey. p.35

Farooq, R. A. \& Haffizullah (1990). "Training and Management for College Principals" Academy of Education Planning and Management, Ministry of Education, Islamabad. p.64

Gay, L. R. (2005). Educational research: Competencies for analysis and application. Islamabad: National Book Foundation.

Goldring, S. H. (1997). “The Principal of Dynamic School” California. p.3

Griffin, R. W. (1982). Report of the National Seminar on Psychological Testing in Pakistan. Islamabad: National Institute of Psychology.p.4

Gupton, L. S. (2003). The Instructional Leadership Box: A handbook for improving practice. London: Sage Publications. p. 3

Hussain, I. (2005). Development of Aptitude Test for the Selection of Educational Managers for Secondary Schools. M.Phil Thesis, Department of Educational Planning \& Management, Faculty of Education. Allama Iqbal Open University Islamabad. p.1

Ibrahim, N. (2011). Preparation and Development of Public Secondary Schools Principals in Kenya. International Journal of Humanities and Social Science, Vol. 1 No. 9 Special Issue - July 2011. pp.291-301

Katozai, M. A. (2002). Preparation for the PCS Screening Test of Senior English Teacher. University Publishers Shop \# 8 - A Afghan Market, Qissa Khwani Peshawar. pp. 139-141

Kenneth, B. B. (1984). Education Administration, Second Edition. Buttler and Tanner Ltd. Great Britain, UK. p.6

Khan, H. (2000). "National Diagnostics of Head Teachers in Pakistan", Improving School Management in Asia Capacity Building for Head Teachers, AEPAM, Ministry of Education, Islamabad.

Khatoon, S. (2008). A Survey of In-Service Training Needs for Heads of Secondary and Higher Secondary Schools. M.Phil Thesis, Department of Educational Planning \& Management, Faculty of Education. Allama Iqbal Open University Islamabad. p.17

Khatoon, Z. (2007). A Study on Training Need Assessment of Heads of F.G. Secondary Schools. M.Phil Thesis, Department of Educational Planning and Management, Faculty of Education, Allama Iqbal Open University Islamabad. p.14

Knootz, H. \& Heinz, W. (1993). Management: A Global Perspective (10th Ed.). New York: McGraw Hill Inc. p.4

Masrur, R. (2003). Thesis writing: A systematic approach. Islamabad: Allama Iqbal Open University.

Mulford, B. (1996). "Do School Principals Make A Difference? Recent Evidence and Implications". Leading and Managing, 2(3), 155-170.

Nelly, T. (2008). Roles, Duties and Responsibilities of School Management Team. Training Manual for Secondary School Managers. Mineduc School Management Kigali. Republic of Rwanda. p.20

Nwankwo, J. I. (1982). Educational Management. George Allen and Unwin Ltd. London, UK. p. 10 


\section{Macrothink}

Obemeata, J. (1984). Secondary school headship in the Nigerian context. In S. Adesina and S. Ogunsaju. (Eds.). Secondary Education in Nigeria, pp.58-84. Ile-Ife: University of Lfe Press.

Paul, K. \& Jacobson, B. (1984). Leadership in Administration: Harper \& Row, Free Press, N. Y. p. 79

Pont, B., Nusche, D. \& Moorman, H. (2008). Improving School Leadership: Vol.1 Policy and Practice. pp.9-10. www.oecd.org/publishing/corrigenda.

Rao, V. S. P \& Narayana, P. S. (1991). "Principles and Practice of Management", New Dehli: Konark Publishers. p.4

Sharma, E. M. (1994). School Administration. Common Wealth Publisher, Ansari Road, New Delhi, India. p.93

Sheikh, R. A. (1985). Training Needs of Demonstration and Managers of Educational Institutions. (Unpublished thesis) Allama Iqbal Open University, Islamabad, Pakistan. pp.3-4

Tahira, R. (2005). Impact of Promoted and Directly Recruited Heads on Students Achievement at Secondary Level o in Punjab. M.Phil Thesis, Educational Planning \& Management Department, Faculty of Education. Allama Iqbal Open University Islamabad. p.1

Terry, R. G. \& Franklin, G. S. (2000). "Principles of Management”, Islamabad: Allama Iqbal Open University Islamabad. p.4

Zaki, W. M. (1988). Educational Management. Islamabad: National Book Foundation pp.1-3, 20 